\title{
要求船位精度に影響を与える要素についての研究
}

\author{
和 気 博 嗣* ・林 祐 司*
}

\section{A Study on the Factors Affecting the Desired Position Fix Accuracy}

\author{
Hirotsugu WAKE and Yuji HAYASHI
}

\begin{abstract}
The position fix accuracy regarded as necessary by ship masters and officers depends upon several factors, such as ship safety related factors and ship operation related factors.

It is our objective to specify these factors and evaluate quantitatively their contributions in this dependency. For that purpose, questionnaire survey was conducted and the analysis was done by use of Analytic Hierarchy Process.

Results show that safety related factors contribute to the dependency more in the harbor area than in the ocean, and also job rank has something to do with the evaluation of the factors in the ocean and coastal area but not in the channel and harbor area.
\end{abstract}

\section{1.はじめに}

世界中の船長・航海士は，あらゆる方法を用い船位を求める作業を行ない，船位を決定しているが，その船位 には程度の差こそあ祦差が常に含まれていることを決定した本人自ら認識している。その時点での船舶が置か れている自然環境・人為的環境・船舶自体の状態・測位方法・その他多くの要素が決定船位に含まれている誤差 の大きさに影響を与兄ているからである。

一方, 彼らは各人の経験と学習により, それぞれの状況下で許容されるべき船位誤差の大きさの基準を持って おり，これを要求船位精度というが，同時に各測位方法における測位精度も認識しており，一定間隔で連続して 測位作業が行なわれる際, 求めた船位が自分達の予測していた船位と大きく異なった場合でその差が自分達の要 求船位精度以上のとき, 別の測位手段で船位を確認しょうとする。

このように要求船位精度は測位システムの精度がぞんなに向上しょうが信頼性が 100 パーセントでないかぎり, その測位システムが正常に作動しているかどうかを確認するらえで重要な要素になってくる。特に将来において 船舶運航の少人数化や自動化が行なわれていくとき, 航海システムの異常の発見や修正に, 当該船舶運航者の要 求船位精度が役立つむのと考光られる。

本論文では, AHP (Analytic Hierarchy Process=階層分析法)(1)を使用し，アンケート調査法によりこの 要求船位精度に影響を及ぼす要素について定量的な評価を試みたのでその結果について述べる。またそれらの影 響度の海域別・職位別傾向についても考察したので述べる。

\section{2. アンケート調查法}

\section{1 アンケート調查の概要}

従来の要求船位精度に関しての研究方法は船体運動（おもにミーイング）と可航幅からその大きさを求める力 法(2)とアンケート調査票によりそれを求める調査法(3)，(4) とがあるが，本論文はA H P の手法に則ったアンケー ト調查法を用いて行なった。

アンケート調查票では, 要求船位精度に影響を与えるであろう要素をあらかじめ特定し, それらを階層化して

* 正会員 神戸商船大学 (厂658 神戸市東灘区深江南町 5-1-1) 
質問を設定した。そして，扣もに日本航海士会会員（1988年 6 月現在，会員数 1,462名）を対象にして，1988年 8月 1 日から同年10月31日まで郵送法によりアンケート調査を実施した。

2. 2 調查票の構成之内容

2. 2.1 構 成

調査票はA 4 用紙 8 枚から成って括りその内訳は，次のと拈りである。

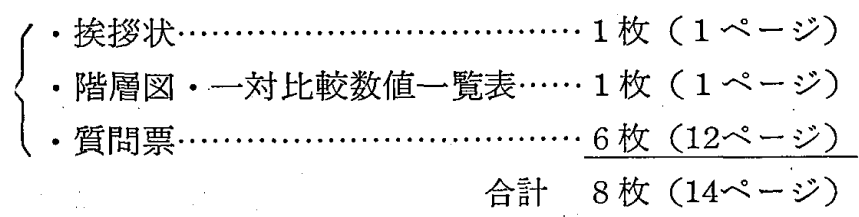

2. 2.2 内 容

（1）年齢，職位，所属会社，実質航海年数についての単一回答形式による質問。

（2）各要素が要求船位精度に与える影響度を海域別に求めるためのAH P による各要素間の一対比較質問。

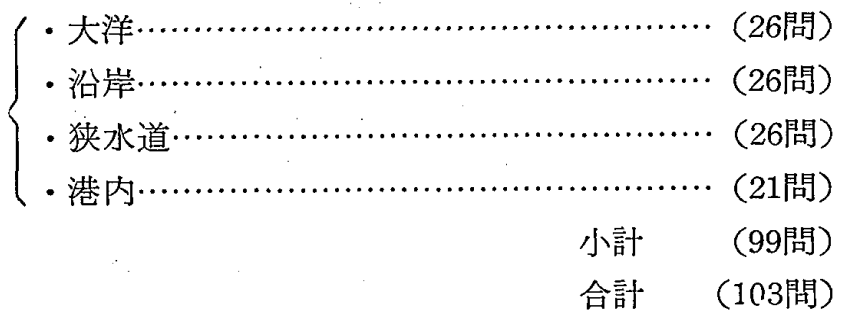

2. 3 用語の定義と要素の選定

2. 3.1 用語の定義

アンケート調査で使用した各用語の定義は次のとおりである。

（1）[要求船位精度]………自船の船位に対する操船者の要求する精度

(2) [海域]. 外航船舶が航行可能な海の一区域で次の 4 種類に大別している。

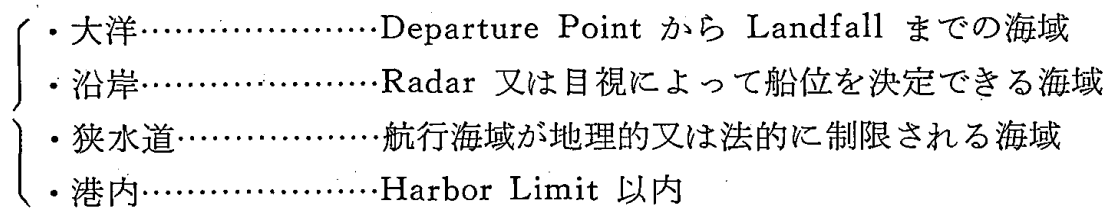

（3）[入港までの時間]………船舶が次の港に入港するまでに必要な時間

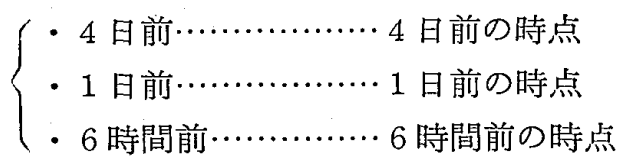

（4）［自船の周囲の状況］……自船を取り巻く自然及び人工の環境

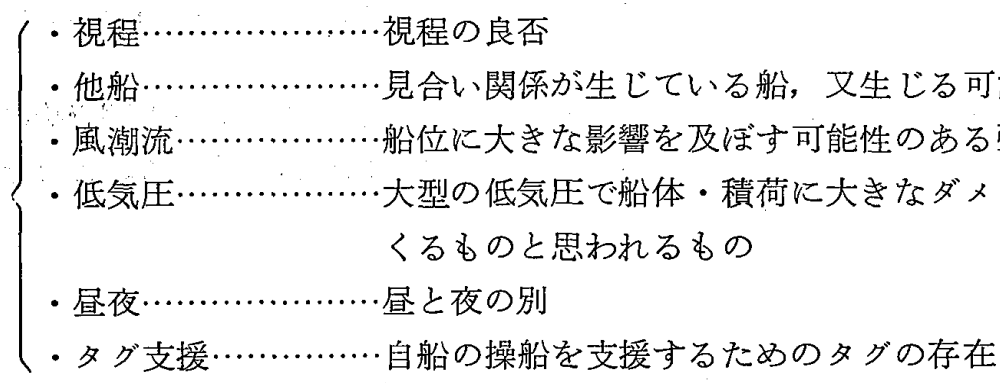

（5）［自船の状態 $]$ ………....自船の種類・速力・船体の大きさ

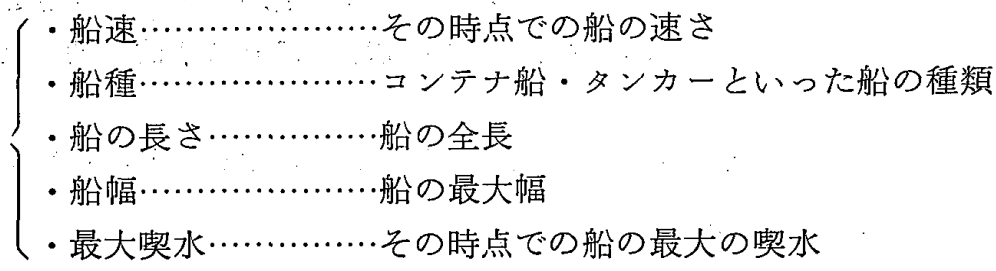




\section{3.2 要素の選定}

要求船位精度に影響を与える要素の選定 方針として，要素の個数は一対比較の回数 をできるだけ少なくするために必要最少個 数で全体を網羅することとした。そして現 役航海士を交えたブレーンストーミングを 用いて，海域別に図 1 および図 2 のように 各要素を選定した。図 1 では 3 つの大要素 として（自船の状態）と（自船の周田の状 況）そして運航状態の代表としての（入港 までの時間)とした。即ち，自船の犆かれ ている外的及び内的環境をこ机ら 3 つの大 要素により代表させたことになる。また小 要素としてそれぞれの下に 5 個・5 個・3 個の代表的な要素を選んだ。

\section{4 一対比較法}

回答者は，各要素間での一対比較を表 1 の評価基準に従って行なった。例えば，(自 船の状態）と（自船の周囲の状況）を一対比較する場 合，前者のほらが後者より若干重要であると評価する 回答者は 3 , 絶対重要と評価する回答者であれば 9 と 回答することになる。また後者のほうが重要であるな らその程度に応じて逆数である $1 / 3,1 / 9$ と回答する。

2. 5 調查票の発送䘛よび回収

調查票と返信用封筒（料金着払い）は，日本航海士 会本部（東京都千代田区楼町 4-5 海事センタービ ル）に一括して送付し，本部にて日本航海土会会誌 “LOOK OUT”に同封され各会員が存在する自宅，

もしくは乘船中の本船に発送した。

その他, 神戸商船大学教官・海技大学校教官および 海技大学校本科学生には直接手渡した。発送先の詳細は表 2 の と括りである。

調查票の最終回収部数は 153 部であり, 発送総部数 1,477 部 に対し回収率は10.4\%であった。

\section{3.'集計方法と集計結果}

3. 1 有効回答者数とAH P 集計方法

3. 1.1 有効回答者数

アンケート回答者 153 名の職位別内訳は次のと括りであり， 職位別年齢・実質航海経験年数の最頻值は表 3 のとおりである。

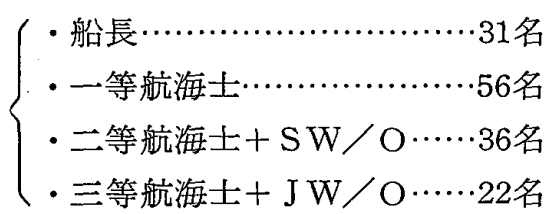

また無効を除いた海域別の有効アンケート調査票の数は，次
表 2 アンケート調查票発送先と部数

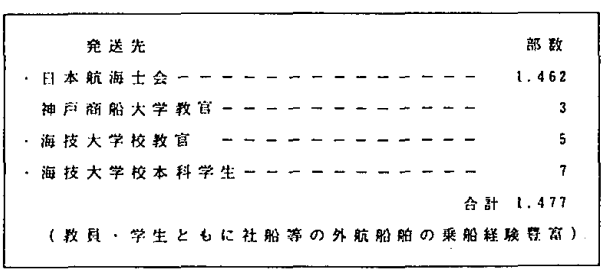

表 3 回答者の職位別年齢・実質航海 経鉤年数

\begin{tabular}{|c|c|c|}
\hline 聇位 & 种命 (†) & 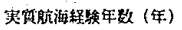 \\
\hline 船長 & 45 以.下 -50 未淽 & 10 以上〜15末萳 \\
\hline 一等航海士 & 40 以上 45 末满 & 10 以上～ 15 末满 \\
\hline 一䇰航海士 $\mathrm{SW} / 0$ & 30 以上 35 末㵧 & 5以.上 10末菭 \\
\hline$\therefore$ 䈉航海士 & 25 以上 -30 末洴 & 3 米满 \\
\hline
\end{tabular}


のと掞りである。

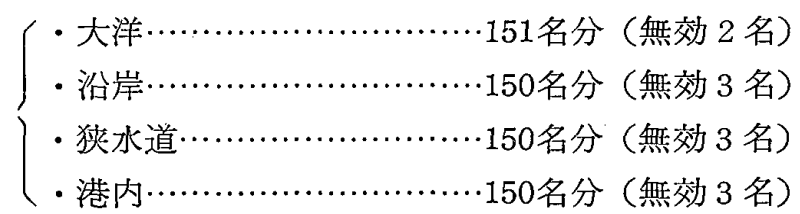

3. 1. 2 A P 集計方法

(1) 整合度のチェックと修正

整合度とは一対比較によって得られた值が全体として首尾一貫した整合性をどれ任ど持っているかる表わした 数值で, 通常の整合度の許容範囲は 0.150 ～ 100 以下が望ましいとされている(1)。本研究では，0.100以下を 採用した。

海域別に150〜151名分の一対比較值を，各人について一人ずつ海 域別に整合度をチェックし 0.100 以下にするため最小限度の修正を 行なった。換言すれば，最初に本人が判断を下したウエイトを基に して整合性を高めるため不都合な最小限の箇所を最小の修正幅で修 正したことになる。また修正は修正幅 0.1 単位で行ない，修正済の 值は1.0〜9.0までと，その逆数をとることになる。表 4 は各海域の 質問数々修正率, 一人当たりの修正個数の平均之分散, 修正後の整 合度の平均と分散をまとめたものである。

このようにして得られた修正後の一対比較值を用いて “グループ 別の一対比較モデル”の作成を行なう。

(2) グループ別の一対比較のモデルの作成, 及びウエイトの算 出

表 4 海域別の質問数と修正個数

\begin{tabular}{|c|c|c|c|c|c|c|}
\hline \multirow[b]{2}{*}{ 海域 } & \multirow[b]{2}{*}{ 質問数 } & \multirow[b]{2}{*}{ 修正率 } & \multicolumn{2}{|c|}{ 修正個数 } & \multicolumn{2}{|c|}{ 修正後の整合度 } \\
\hline & & & 平均 & 分散 & 平均 & 分散 \\
\hline 大洋 & 26 & 0.130 & 3.37 & 2.37 & 0.049 & 0.021 \\
\hline 沿岸 & 26 & 0.116 & 3.02 & 2.41 & 0.051 & 0.022 \\
\hline 侠水道 & 26 & 0.109 & 2.83 & 2.27 & 0.049 & 0.020 \\
\hline 港内 & 21 & 0.064 & 1.35 & 1.65 & 0.031 & 0.014 \\
\hline
\end{tabular}

表 5 海城別の全貣のモデル

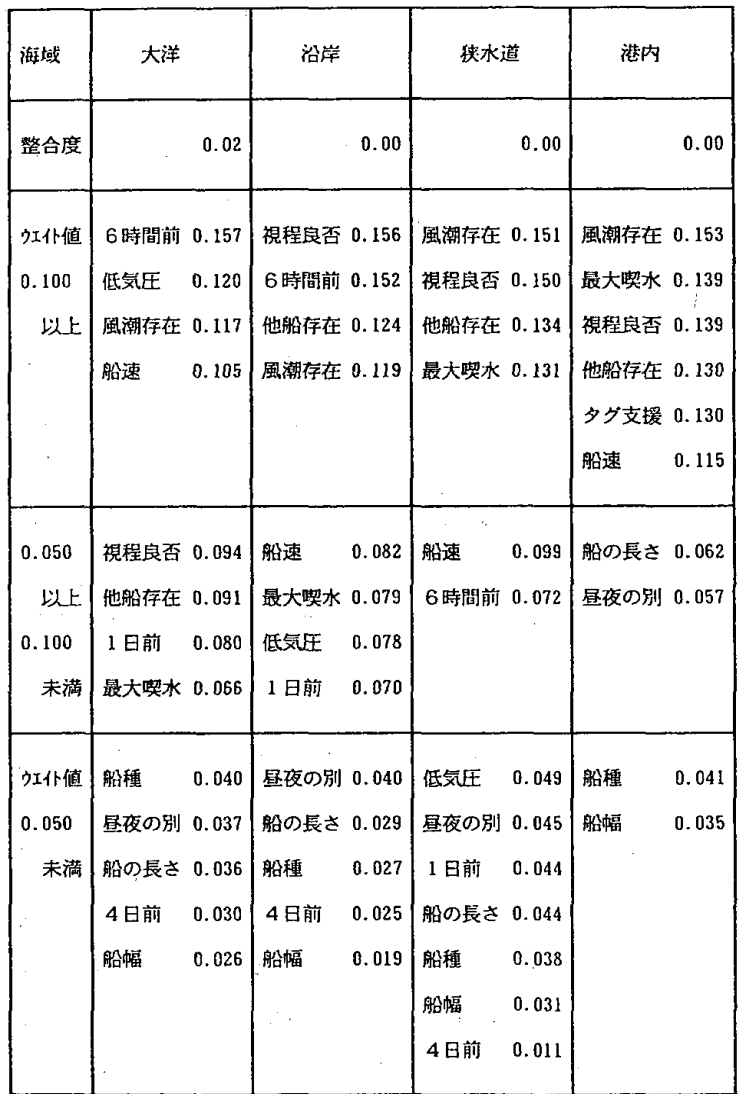

表 6 職位別モデル（大洋航海）

\begin{tabular}{|c|c|c|c|c|c|c|c|c|}
\hline 躘位 & \multicolumn{2}{|c|}{ 船㙊 } & \multicolumn{2}{|c|}{ 一等航海士 } & \multicolumn{2}{|c|}{$=$ 航士 $+5 W / 0$} & \multicolumn{2}{|c|}{ 三航士 $+J W / 0$} \\
\hline 整含度 & & 0.00 & & 0.01 & & 0.01 & & 0.01 \\
\hline 殁仆値 & 6 時䦓前 & 0.153 & 低気压 & 0.137 & 6 時間前 & 0.215 & 低気正 & 0.150 \\
\hline 0.100 & 低気圧 & 0.146 & 6 時間前 & 0.131 & 低気压 & 0.163 & 視程良否 & 0.126 \\
\hline 以上 & & & 視程良否 & 0.119 & 1日前 & 0.108 & 他船存在 & 0.121 \\
\hline & & & 胎速 & 0.113 & & & 6時間前 & 0.115 \\
\hline & & & & & & & 船速 & 0.101 \\
\hline 加仆値 & 視程良否 & 0.098 & 地船存在 & 0.093 & 他船存在 & 0.088 & 風潮存在 & 0.093 \\
\hline 0.050 & 船速 & 0.097 & 風潮存在 & 0.092 & 船速 & 0.085 & 最大喫水 & 0.060 \\
\hline 以上 & 1 日前 & 0.094 & 最大喫水 & 0.076 & 風潮存在 & 0.079 & 1 日前 & 0.055 \\
\hline 0.100 & 風潮存在 & 0.089 & 1 日前 & 0.063 & 視程良否 & 0.061 & & \\
\hline 末满 & 他船存在 & 0.077 & & & 最大喫水 & 0. 053 & & \\
\hline & 最大㗪水 & 0.063 & & & & & & \\
\hline 力工仆値 & 昼夜の別 & 0.041 & 船種 & 0.047 & 4日前 & 0.040 & 船の長さ & 0.042 \\
\hline 0.050 & 船種 & 0.040 & 宣夜の別 & 0.042 & 㚖夜の別 & 0.032 & 昼夜の別 & 0.041 \\
\hline 未满 & 船の長さ & 0.038 & 船の長さ & 0.039 & 船種 & 0.031 & 船種 & 0.040 \\
\hline & 4日前 & 0.036 & 船幅 & 0.027 & 朌の長さ & 0.026 & 船幅 & 0.031 \\
\hline & 船幅 & 0.029 & 4日前 & 0.022 & 船幅 & 0.019 & 4 日前 & 0.025 \\
\hline
\end{tabular}


［例］（大洋）での (船長) の一対比較のモデルの作成。 各船長の大洋に和衫る一対比較の生の值（修正したも のは修正済の值) の幾何平均を求め, 一対比較のモデル を作り，その值からウェイト值を求め，それが（大洋） での (船長) のモデルとなる。

\section{2 集計結果}

同様の手順で求めた海域別の全員のモデルが表 5 であ り，海域・職位別のモデルが表 6 (大洋)・表 7 (沿岸)・ 表 8 (狭水道) および表 9 (港内) である。表 5 では, 4 つの海域別に全員のモデルの整合度を掲げ，以下，ウ エイト值の大きい順に 3 つのクラスに分けて小要素とウ エイト值を表示している。それぞれのクラスは 0.100 以 上，0.050 以上 0.100 未満，0.050未満となっている。 表 6 〜表 9 も同様の方法で職位別のモデルに付いてまと

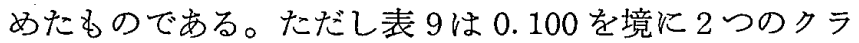
スに分けられている。

表 8 職位別モデル（狭水道通）

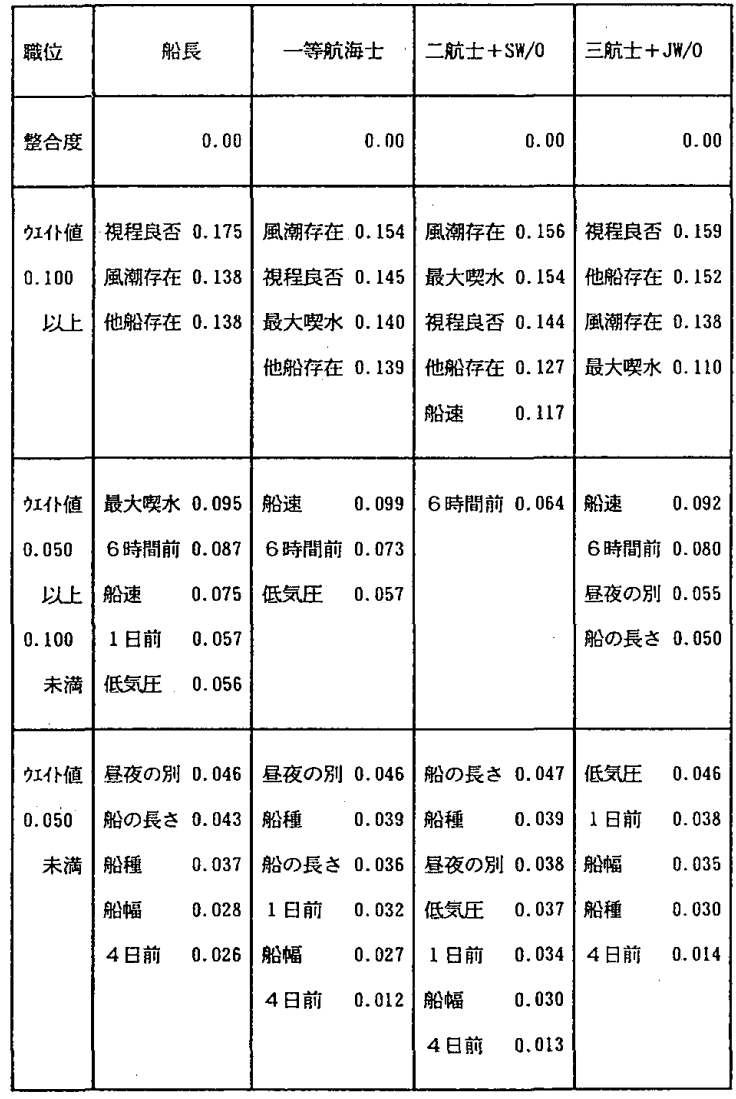

表 7 職位別モデル（沿岸航海）

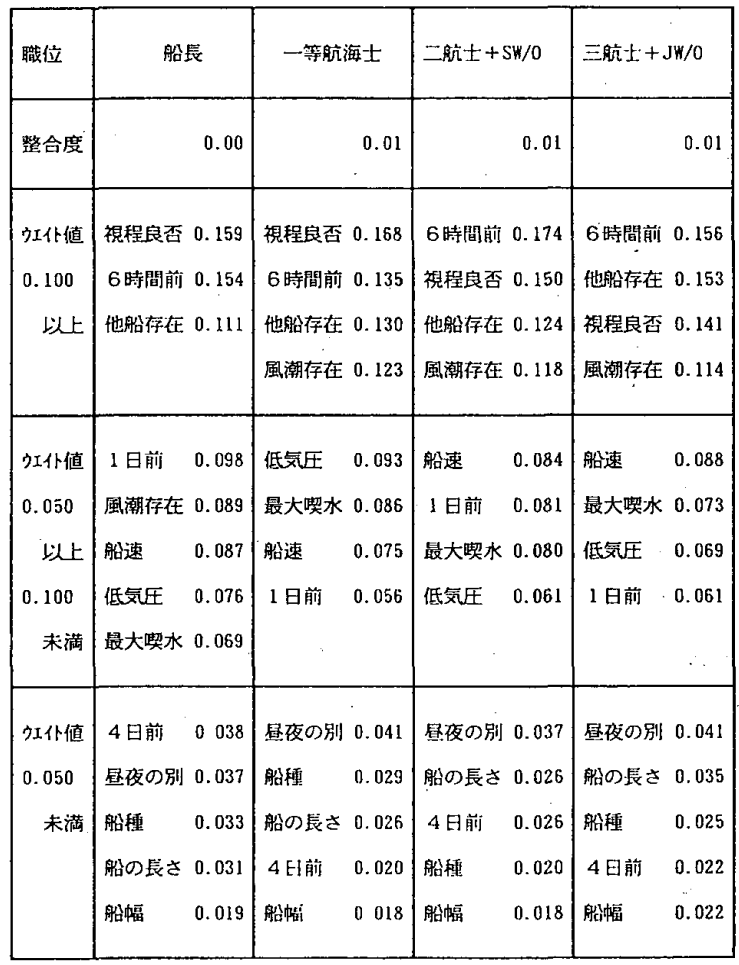

表 9 職位別モテデル（港内）

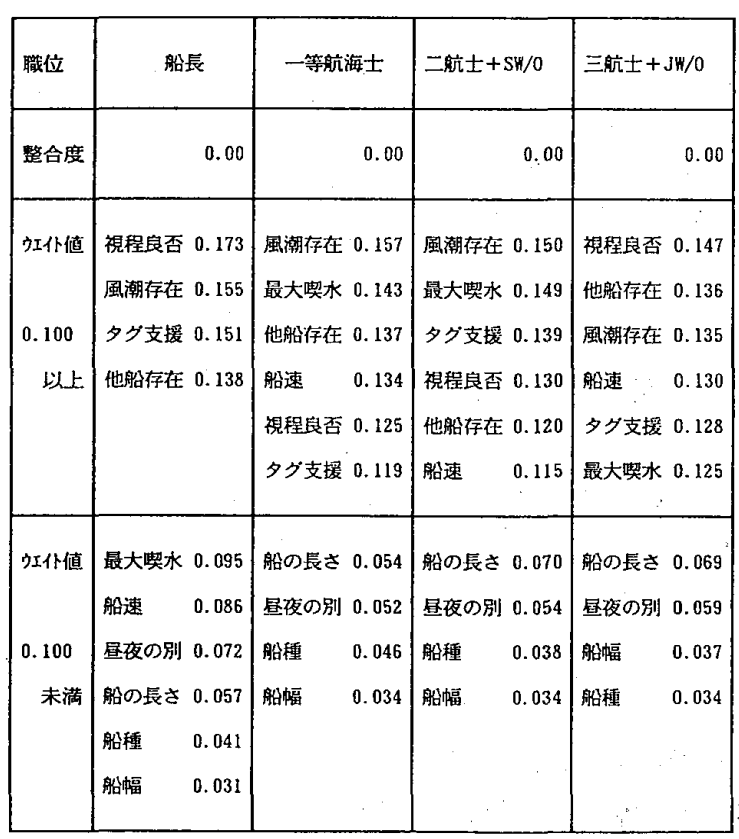

\section{4. 各モデル間の比較と考察}

港内に括ける (所要時間) の 3 小要素と (低気圧), 大洋・沿岸・狭水道に和ける (タグ支援) は 0.000 と表示

して次の 2 つ項目について考察した。

$\int \cdot$ 各海域別全員のモデルの比較。

「・各海域職位別モデルの比較。 
4. 1 各海域別全員のモデルの比較

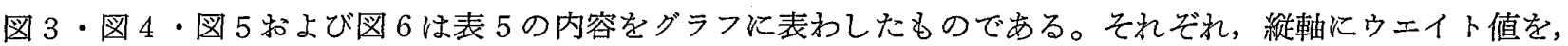
横軸に海域をとっている。図 3 は大要素である (所要時間), (周囲状況) および (自船状態) の海域別の变化を 示したものである。(周囲状況)は 4 つの海域にわたって常に最も大きな値をとっているのに比べ（所要時間） と（自船状態）に対するウエイト值は，大洋・沿岸までは，拮抗しているが，狭水道・港内では両者の差は大き く開いてくる。

図 4 は (所要時間) の3 小要素の海域別変化を示したものである。ウェイト值の大きさの順は, 4 つの海域に わたって同一であり，逆転することはなく，海域が狭まるにつれてこれらの要素のウェイト值は減少する傾向を 示している。

図 5 は (周囲状況) の5ちの6 小要素の海域別変化を示したものである。ウェイト值は多少の変動はあるもの の，(風潮存在)，(視程良否）および（他船存在）に関しては海域が変わっても高い值で推移している。一方(低 気圧）は海域が狭まるにつれてその值を急激に減少させ（タグ支援）は港内で比較的大きい值を示している。

図 6 は (自船状態) のうちの 5 小要素の海域別変化を示したものである。(船種)，(船の長さ）抢よび（船幅） のウエイト值は，4つの海域にわたって小さく，その順位もほぼ同一であるが，（船速）と（最大契水）のウエ イト值の大きさとその順位は沿岸を境にして大きく逆転している。

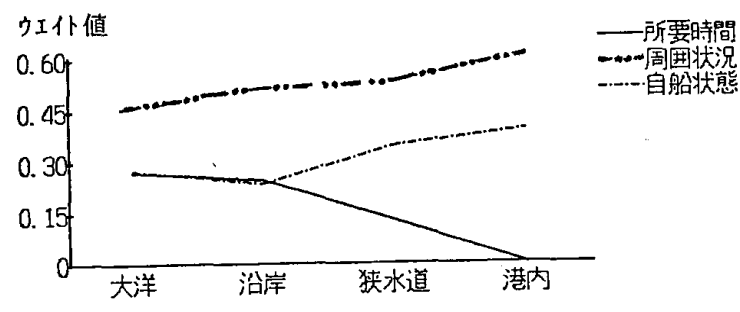

図 3 所要時間·周囲状況・自船状態の海域別変化

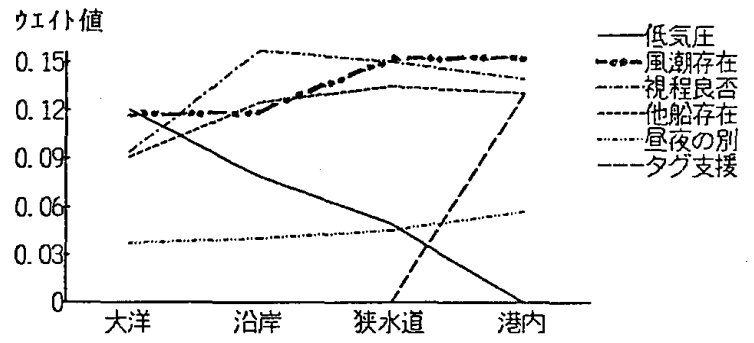

図 5 周囲状沅の 6 要素の海域別変化

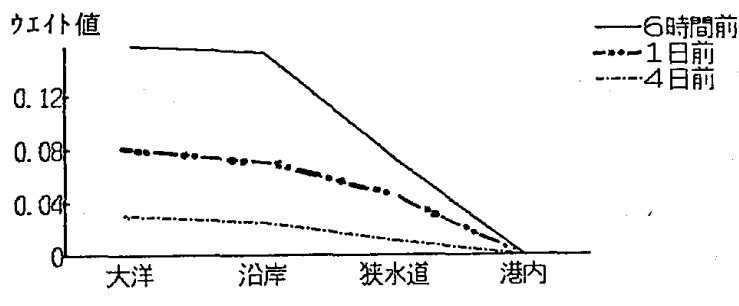

図 4 所要時間の 3 要素の海域別変化

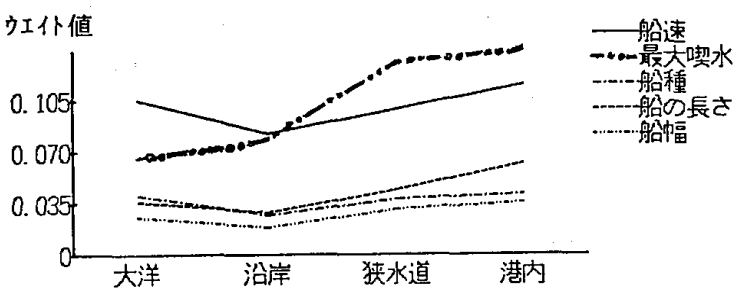

図 6 自船状態の 5 要素の海域別变化

以上 $4 つ$ づラフから言えることは，海域が狭まるにつれて船の運航，特に運航スケジュール維持に関する要 素より，船の安全に関する要素の汪らが，要求船位精度に大きな影響を与えているといらことである。また（周 囲状況) のうち(風潮存在)，(視程良否）および（他船存在）の3 小要素は海域が変化しても常に要求船位精度 に大きな影響を与えていると言える。一方（自船状態）のうちの（船速）も海域にとらわれず比較的大きい影響 を与文（最大契水）快水道・港内と飛躍的にその影響力を強めている。また（船の長さ）す値こそ小さいが (最大契水) と同様の傾向を示している。

4. 2 各海域職位別モデルの比較

図 7 図14は縦軸にウェイト值を，横軸に職位をとって，ウェイト值の職位別変化を示したものであり，海域 別に表わしている。

(1) 大 洋

図 7 は大要素である (所要時間)，(周囲状況）および (自船状態) の職位別の変化を示したものである。（周 曲状沉）は 4 つの職位にわたって最も大きな值をとっているのに比べ（所要時間）と（自船状態）に対するウ エイト值の大ささの順位は（船長，二等航海士）グループと（一等航海士，三等航海士）グループで異なる。

図 8 は (所要時間) の 3 小要素の職位別変化を示したものである。ウエイト值の大きさの順位は，4つの職位 


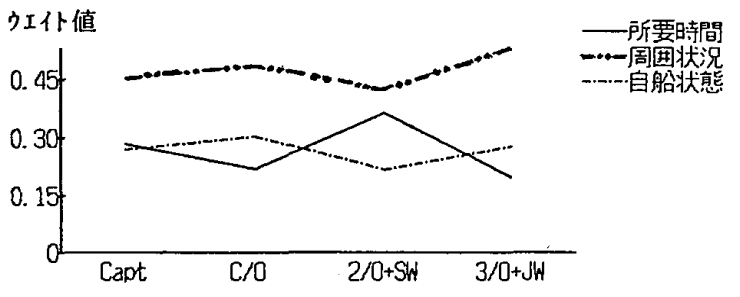

図 7 所要時間·周囲状況・自船状態の職位別変化 （大 洋）

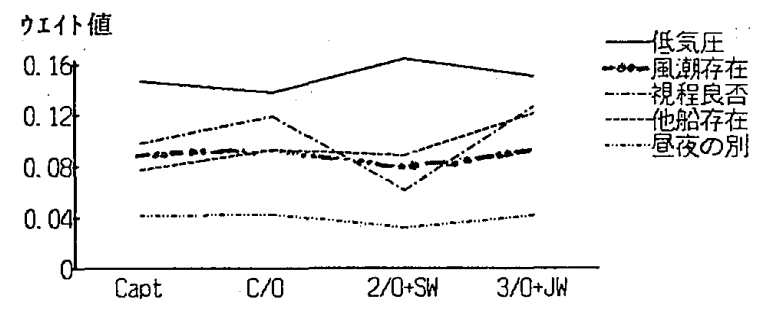

図 9 周囲状況の 5 要素の職位別変化

(大 洋)

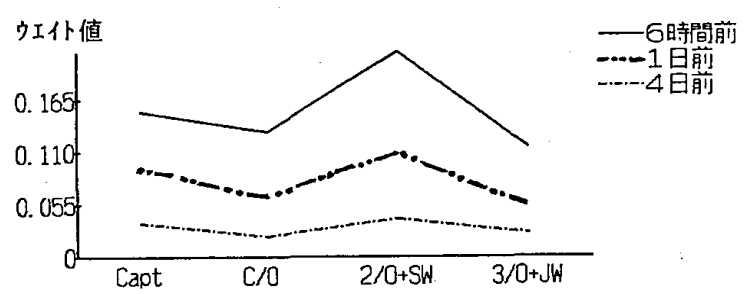

図 8 所要時間の 3 要素の職位別変化

(大 洋)

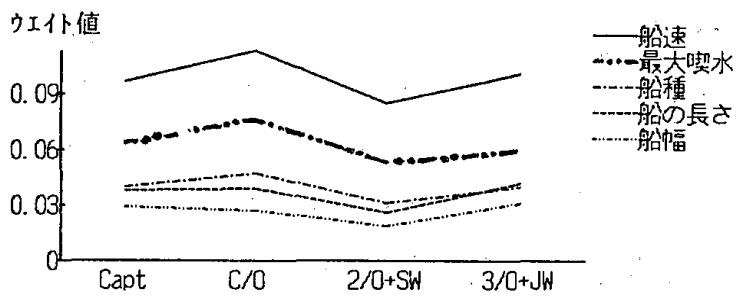

図10 自船状態の 5 要素の職位別変化 (大 洋)

にわたって同一であるが二等航海士の（6時間前）のウエイト值が笑出しているのが顕著である。

図 9 は (周囲状況) の 5 小要素の職位別変化を示したものである。ウェイト值の大きさとその順位は，（低気 任)，(風潮存在）および（昼夜の別）に関しては 4 つの職位にわたって注注同じであるが，(視程良否）之（他 船存在）は大きな凹凸がある。特に二等航海士の（視程良否）に対するウエイト值の落ら込みが大きい。

図10は (自船状態) の 5 小要素の職位別変化を示したものである。ウエイト值の大きさの順位は，4つの職位 にわたってほぼ同一である。

以上 4 つのグラフから明らかなことは, 大洋航海中の (所要時間), (周囲状況) 扣よび（自船状態）に対する 評価が (船長，二等航海士) グループと（一等航海士，三等航海士）グループに分かれているといらことである。 その理由としては，前者が大洋航海中に掠いて通常，航海関連の仕事を主体にしていることがあげられ，そのた めスケジュール維持に関係する (所要時間) に対しての評価が大きくなったといえよう。また後者は大洋航海中 に括いて積荷関連の仕事を主体にして拈り，そのため船体の姿勢制御に代表される（自船状態）に対しての評価 が大きくなったと考えられる。このよらに大洋航海中の仕事の分担により各要素に対する評価の傾问が異なって くるといえる。特に大洋航海中の二等航海士の入港 (6 時間前) のウエイト值が極めて高いのは，外航定航船の スケジニールの常で, 朝一番の入港のため午前の $0-4$ 直でスピード調整を行ならためと考えられる。また引等 航海士の（視程良否）と（他船存在）に対する評価が大きいのは航海経験未熟のためと考学られる。

沿岸に和いても大洋ほど顕著ではないが同様の傾向が現われている。

\section{(2) 狭水道}

図11は大要素である（所要時間), (周囲状況) 括よび（自船状熊）の職位別の変化を示したものである。（周 囲状況）は 4 つの職位にわたって最も大きな值をとっているのは大洋・沿岸と同様であるが，ここで初めて（自 船状態) と（所要時間）に対する評価がはっきりし，両者の間にウェイト值の差がすべての職位にわたってあら われる。即ち, 大洋・沿岸の昜合には（自船状態）と（所要時間）の要素は各職位によって多少の山凸が見られ るものの両要素とも帛ぼ $0.25 \sim 0.30$ 程度の值をとっており, 明らかな差はあらわれなかった。しかし狭水道に 特いては (自船状態) が 0.35 程度，(所要時間）が 0.15 程度と両者の差がはっきりと現われている。

図12は (所要時間) の3 小要素の職位別変化を示したものである。ウエイト值の大きさの順位は，4つの職位 にわたって同一であり, 全体に対しての（所要時間）の割合が低下したためその変動の值は極めて小さなものと なっている。

図13は（周囲状況）の 5 小要素の職位別変化を示したものである。ウエイト值の大きさとその順位は，（風潮 存在), (視程良否), (他船存在), (低気圧) および (昼夜の別) ともに 4 つの職位にわたってほぼ同じであるが, 


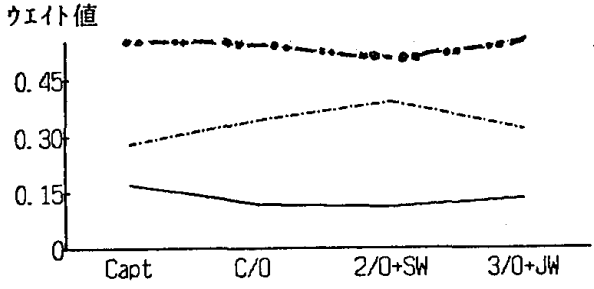

図11 所要時間·周团状況・自船状態の職位別変化 （狭水道）

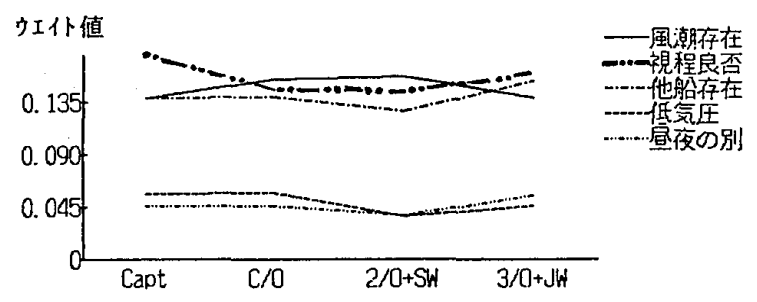

図13，周囲状沉の 5 要素の職位別変化 （狭水道）

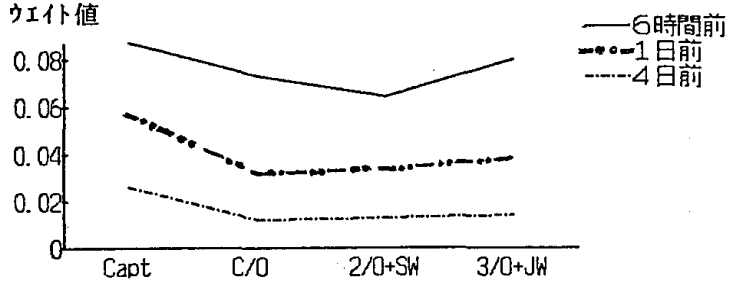

図12，所要時間の 3 要素の職位別変化 （狭水道）

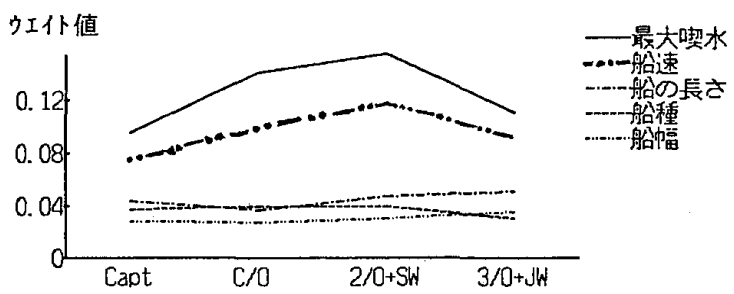

図14 自船状態の 5 要素の職位別変化

（狭水道）

ウェイト值から（風潮存在）（視程良否）および（他船存在）グループと（低気圧），昼夜の別）グループに大 別できる。

図14は（自船状態）の5 小要素の職位別変化を示したものである。ウエイト值の大きさの順位は，4つの職種 にわたってほぼ同じであるが，（一等航海士，二等航海士）グループでは（最大喫水）と（船速）のウエイト值 が (船長, 三等航海士) グループに比較して大きくなっている。ぬた（最大契水），(船速）グループと（船の長 さ)，(船種）および (船幅) グループとの間にウエイト值の差が生じている。

以上 4 つのグラフから明らかなことは, 狭水道通峡中の要求船位精度に影響する各要素に対する評価は，船長・ 一等航海士・二等航海士和よび三等航海士ともに類似してきており，他の海域と比較して順位の逆転が少なくな っている。このことから狭水道通峡中の要求船位精度に比較的大さな影響を与える要素が (風潮存在), (視程良 否), (他船存在), (最大契水) および (船速) に限定されており, それら要素に対して船長・一等航海士・二等 航海士および三等航海士ともに類似した評価を行なっているといえる。

港内に拉いても狭水道と同様の傾向が現われている。

\section{5. おわりに}

以上の研究の結果, 次の各項目について明らかになった。

（1）AH Pを用い各海域別職位別の要求船位精度に影響を及ぼす要素を定量化し，各職位間の相違が明確に なった。

（2）AH Pを用い各海域別の要求船位精度に影響を及ぼす要素を定量化し，各海域間の相違が明確になった。 本研究は, 評価法にAH Pを使用し, 要求船位精度に影響を与える要素について定量的な評価を行ないとりま とめたものであり，研究の一つの向を示した。これからますます増加するであろう混乗船の安全運航の確保の ためにも同様の調査を外国人船長・航海士にまで広げ，国別の船長・航海士の要求船位精度に対するセンスの相 違を明らかにしたいと考えている。また本研究の結果が測位システムの開発・運用の一助になれば著者らの望外 のしあわせである。

最後に，船員雇用体制が大きく変りつつある中で職務多忙の折，今回のアンケート調査に積極的に御協力頂い た各船会社・日本航海士会並びに各船長・航海士の方々に，また本研究に対して有益な御意見を戴いた神戸商船 大学の三好雄一教授に深甚の謝意を表します。 
参 考 文 献

(1) THOMAS L. SAATY: The Analytic Hierarchy Process, McGRAW-HILL International Book Company NEW YORK, 1980 .

（2）飯島幸人：近距離航行に拈计る要求船位精度, 日本航海学会誌 “航海” 第43号, pp. 10-15, 昭和49年 6 月.

(3) CAPT. D. D. CLAGGERT: Maritime Aids to Navigation in the Short Distance Maritime Environment, NAVIGATION (U. S. A.) Vol.17 No.1 Spring pp. 13-19, 1970.

(4) E. B. BLOOD: Navigation Aid Requirements for the U. S. Coastal/Confluence Region, NAVIGATION (U. S. A.) Vol. 20 No. 1 Spring pp. 68-76, 1973.

（5）刀根 薫：ゲーム感覚意志決定法, 日科技連, 昭和61年 3 月.

(6) THOMAS L. SAATY: Decision Making for Leaders, WADSWORTH Inc. CALIFORNIA, 1982.

質 疑 応 答

林 尚吾 (東京商船大学)：要求船位精度を決める三大要素の一つとして（入港までの時間）をあげられていま す。これは運航スケジュールの確保が重要な要素として評価されたものと推察されます。従来からの要求船位 精度の考光方には安全の確保が大きくとりあげられていますが, 安全の要素はどのよらに三大要素にとりこま れ，展開されるのでしょらか。

林 祐司：AH Pでは同一階層間の各要素が互いに独立か，またはとれに近くなければならないといら条件があ り，船舶の安全確保という要素をこの階層図に組み込むと，その条件を満たせなくなります。すなわち自船の 周团の状況と自船の状態という要素に船舶の安全確保についての要素を包含しているといらことです。

また (入港までの時間) は運航スケジュールの維持とともに港外までのアプローチ針路決定に大きな影響力 を持って拉り，一般商船では要求船位精度に影響を与兄る重要な要素であると考兄られます。 